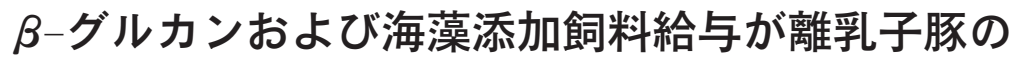 発育と免疫能に及ぼす影響
}

\author{
小野寺渉 1 加地拓己 ${ }^{1} \cdot$ 清水ゆう子 $^{2} \cdot$ 吉野淳良 $^{2} \cdot$ 小林 仁 $^{3} \cdot$ 須田義人 ${ }^{3} \cdot$ 鈴木啓— $^{1}$ \\ 1 東北大学大学院農学研究科, 仙台市青葉区 981-8555 \\ 2 宮城県畜産試験場, 大崎市 989-6445 \\ 3 宮城大学食産業学部, 仙台市太白区 982-0215
}

(2007.8. 13 受付, 2008. 6. 2 受理)

\begin{abstract}
要 約離乳直後の子豚への飼料添加物給与の有効性を, 発育と末梢血中免疫形質から検討した. 試 験 1 では 3 週齢で離乳させたランドレース種 12 頭を $\beta$-グルカン $0.025 \%$ 添加区 ( $\beta$ 区), 海藻 $0.05 \%$ 添 加区 (海藻区), 対照区に4 頭ずつ分け 7 週齢まで試験し, 試験 2 では 3 週齢で離乳させたデュロック種

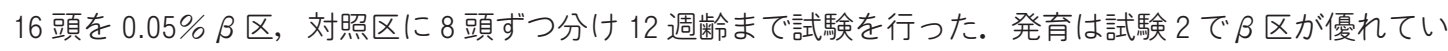
た $(P<0.05)$. 免疫形質は試験 1 では $\beta$ 区, 海藻区で総白血球数（5 週齢）と補体別経路活性（7 週齢） が対照区より高く $(P<0.05)$, 顆粒球とリンパ球の比率は試験 1 (7 週齢), 試験 2 (5 週齢) で対照区 が $\beta$ 区より大きい割合 $(P<0.05)$ を示した．以上から離乳直後の子豚の飼料への $\beta-$ グルカン添加に よって発育が改善される可能性が示唆されたが, 免疫形質への有効性は明確ではなかった.
\end{abstract}

日本畜産学会報 79 (3), 377-383, 2008

離乳期の子豚は生理的, 免疫的に最も無防備かつ不安 定な状態にあり，この時期の子豚の疾病対策は農場の生 産性を大きく左右する（全国家畜畜産物衛生指導協会 2000)。その対策として主に抗菌性飼料添加剤が使用さ れてきた.しかし近年, 食の安全性への関心の高まりか らヨーロッパなどの諸外国をはじめ, 日本でも家畜への 抗菌性飼料添加剂の使用が見直されており(小林 2004), 様々な代替添加物の有効性が検討されている. その代替 物質の候補に免疫形質を活性化し, 疾病に対する防御反 応を促進する可能性を持つ $\beta-$ グルカンと海藻がある.

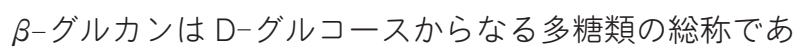
り，現在では酵母壁からその粉末が抽出・精製され，北 欧では主に魚類の養殖において利用されている. 免疫調 整物質として特に自然免疫に作用し, サイトカイン産生 を増加させる事 (Seljelid ら 1987 ; Hoffman ら 1993), ま た離乳期の子豚においても発育改善や免疫形質の活性 化に効果のある事が過去に複数報告されている（Schoenherr ら 1994 ; Dritz 1995 ; Hiss と Sauerwein 2003 ; Mao ら 2005 ; Eicher ら 2006 ; Hahn ら 2006 ; Li ら 2006). 海藻はヒ卜においては抗癌・抗酸化作用など椂々な有効 性を持つ事が確認されており, 食品のみならず家畜用飼 料としても利用されてきた（山田2004）。子豚では飼料 中への海藻添加によって発育が改善される事が報告され ている (Grinsteadら 2000 ; Turnerら 2002).しかしこ
れまで報告されているそれら添加物の免疫形質への効果 は in vitroによる試験が多く, in vivoでの例は少ない。 また発育に関しても報告によって有効性が異なり，一定 の見解は存在していない.

したがって本研究において $\beta$-グルカン, 海藻の抗菌 性飼料添加剂の代替物質としての有効性を検証するた め, 両物質の添加給与が離乳直後の子豚の発育と末梢血 中の免疫形質に与える影響を調查した。試験 1 では $\beta-$ グルカンと海藻粉末を, 試験 2 では試験 1 で免疫形質に 関して影響のあった $\beta$-グルカンを市販の子豚用飼料に 添加し, 再度調查を行った。

\section{材料および方法}

\section{1. 飼料}

本試験においてベースとなる離乳後の飼料は抗菌性飼 料添加剂が入っている市販の子豚用飼料を用いた。試験 1 では 3 週齢で離乳後に「うるおいMax」を，5 週齢以降 は「なかなかMax」（ともに日本配合飼料，宮城県塩釜 市）を用い, 試験 2 では同様に 3 週齢で離乳後「子豚え つけ」,「子豚すこやか」,「子豚はつらつ」,「北日本くみ あい飼料 A 段階飼料」（すべて北日本組合飼料，宮城県 石巻市）を平均体重に合わせてステージごとに使用し た.

添加した $\beta-$ グルカンはパン酵母由来 $\beta-1.3 / 1.6$ グルカ

連絡者：鈴木啓一（fax：022-717-8692，e-mail : k1suzuki@bios.tohoku.ac.jp） 
小野寺・加地・清水・吉野 ・ 小林 · 須田・鈴木

ン粉末である商品名マクロガード（Biotec Pharmacon ASA, トロムソ, ノルウェー) を使用し, 添加濃度は試験 1では Schoenherr ら (1994)やDritzら (1995) が最もブ 夕の増体が優れる事を報告している $0.025 \%$ とした。海 藻はアスコフィラム・ノドサムを主成分とする商品名ア ルギフローラ（神協産業, 山口）を使用し, 添加濃度は 現在の一般的な商業ベースで利用されている $0.5 \%$ とし た。前述したように $\beta$-グルカンの有効な添加濃度は報 告によって異なり, 試験 1 での $0.025 \%$ 添加では発育に

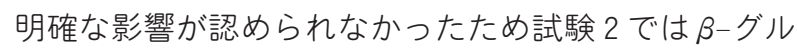
カンの濃度をSchoenherr ら (1994) が 0.025\%にに次いで 増体に良い影響を与える事を報告している $0.05 \%$ に変 更して調查を行った。

\section{2. 供試動物と飼育方法}

試験 1 ではランドレース種妊娠雌豚 1 頭を宮城大学付 属農場に導入し, 生まれたランドレース種 12 頭を 3 週 齢で離乳させ，添加試験を開始した，飼料区は飼料中に 何も添加しない対照区, $\beta-$ グルカン $0.025 \%$ 添加区 ( $\beta$ 区), 海藻 $0.5 \%$ 添加区の 3 区とし, 体重差が無いように 4 頭ずつ区分けし，7 週齢まで飼育した. 試験 2 では宮城 県畜産試験場で飼育している3 頭のデュロック種雌豚か ら生まれたデュロック種 16 頭を 3 週齢で離乳させ, 種 雌豚 1 頭からの子豚の数が両区で均等かつ体重差がない ように区分けし， $0.05 \% \beta$ 区，対照区に 8 頭ずつ区分け して12 週齢まで飼育した。両試験を通してブタはパ ドック付の豚房で不断給餌, 自由飲水の条件下で群飼し た。なお試験 2 において対照区の子豚 1 頭が肢蹄傷害に よって発育が極端に遅れたため試験から除外した。試験 1 では生後 3，4，5 および 7 週齢で，試験 2 では生後 3, 5，7，8 および 12 週齢でそれぞれ保定したブ夕の頚静脈 から採血を行い, その後体重測定を行った. また異種抗 原に対する反応性を比較するため, 試験 1 では 6 週齢, 試験 2 では 6 週齢と 11 週齢に $10^{8} / \mathrm{mL}$ に調製した羊赤 血球（SRBC） $1 \mathrm{~mL}$ を筋肉内に接種した.

\section{3. 血液サンプル}

採血後の全血は総白血球数測定用として EDTA2 ナト リウム入り真空採血管，その他の免疫形質測定用にへパ リンナトリウム入り真空採血管に分注し, 分注後は穏や かに攪找し，氷冷した。ヘパリンナトリウム入り真空採 血管の全血は貪食能活性と総白血球数の測定，また顆粒 球とリンパ球の比率を測定するための塗沫標本作りに使 用した. 全血による免疫形質の測定後, 血液は $720 \times g$, $4^{\circ} \mathrm{C}$ の条件下で 10 分間遠心し, 分離した血漿を $-80^{\circ} \mathrm{C}$ で保存した。血漿を使用する際は常温で溶解させ, 溶解 後は速やかに測定に用いた。

\section{4. 測定形質}

発育形質として体重, 免疫形質として貪食能活性, 総 白血球数, 補体別経路活性, 顆粒球とリンパ球の比率, SRBCに特異的な抗体産生能を測定した。貪食能活性は
全血に含まれる白血球の貪食細胞がザイモザンを異物と して領食する際に生成する活性酸素をケミルミネッセン ス法により測定し, 発光総面積量を貪食能の強さとし た. 総白血球数は全血を希䣋後, 溶血剂を加えて溶血さ せたものを自動血球計数器によって測定した。補体別経 路活性は調製したウサギ赤血球溶液にサンプル血漿を加 える事で補体による溶血反応を起こし，その時の吸光度 の違いを活性の強さとした。顆粒球とリンパ球の比率は ディフ・クイック染色した全血の塗沫標本を光学顕微鏡 で観察し，それら細胞の比率を計数した。抗体産生能の 測定はあらかじめ個体に接種しておいたSRBC を抗原 とし, 血漿中の抗 SRBC IgG 濃度をELISA 法によって測 定した。標準曲線はランダムに選ばれた個体 5 頭の 3 週 齢時の血漿を用いて作成し，これに対する相対的な抗体 産生量を抗体価とした。

なお本試験は国立大学法人東北大学動物実験等に関す る規定に基づいて行われた.

\section{5. 統計解析}

統計解析はSAS プログラムの GLM プロシージャに より試験 1 では飼料区と性，その交互作用を要因とす る, 試験 $2 て ゙ は$ 飼料区, 性, 母親, またそれらの交互作 用を要因とする分散分析を行い，飼料区の影響が有意で あった形質について Duncanの多重比較検定を行った。 なお表, 図中には飼料区の違いによる結果のみ記載し た.

\section{結果および考察}

\section{1. 発育形質}

表 1 には試験 1 で用いたランドレース種子豚の体重と 3 週齢から 7 週齢までの一日平均増体量の結果を, 表 2 には試験 2 で用いたデュロック種子豚の体重と 3 週齢か ら 12 週齢までの一日平均增体量を示した。試験 1 では 飼料区による発育の違いは無かったが, 試験 2 では 9 週 齢以降に $\beta-$ グルカン添加区の体重が対照区に比べて大 きい傾向（9 週齢 : $P<0.05,12$ 週齢 $: P<0.10)$ があ り，一日平均増体量においても $\beta$ 区 $(540 \mathrm{~g} /$ 日) が対照区 $(487 \mathrm{~g} /$ 日) に比べ大きくなる傾向 $(P<0.10)$ があった. 試験 1 において 7 週齢まで体重の変動係数の推移は海 藻， $\beta$ 区が対照区に比べ小さくなっており，発育が斉一 になる効果が期待されたが，試験 2 では $\beta$ 区が対照区に 比べて平均して $5 \%$ ほど大きい結果となった.

効果の違いはあるものの両試験を通して $\beta$ 区で最終 週齢体重と一日平均増体量が大きく, 飼料中への $\beta-$ グ ルカン添加によって発育が改善される可能性が示唆され た. Dritzら（1995）は離乳期の子豚に抗菌性飼料添加剂 を含む飼料に $\beta$-グルカンを $0.025 \%$ 添加した場合，一日 平均增体量だけでなく一日平均飼料摂取量も対照区に比 ベ増加する事を報告しており, Hiss と Sauerwein (2003) は離乳期の子豚に対して抗菌性飼料添加剂を含む飼料中 


\section{子豚への飼料添加物給与の影響}

Table 1 Effects of $\beta$-glucan and seaweed on body weight $(\mathrm{kg})$ and average daily gain (ADG) from 3 weeks to 7 weeks of age (Exp. 1)

\begin{tabular}{|c|c|c|c|c|c|c|c|c|}
\hline \multirow[b]{2}{*}{ Treatment } & \multirow[b]{2}{*}{$\mathrm{N}$} & \multicolumn{6}{|c|}{ Weeks of age } & \multirow{2}{*}{$\frac{A D G \text { (g/day) }}{\text { w3-w7 }}$} \\
\hline & & w0 & w2 & w3 & w4 & w5 & w7 & \\
\hline Control & 4 & $1.2 \pm 0.1$ & $4.5 \pm 0.5$ & $5.0 \pm 0.4$ & $8.1 \pm 0.8$ & $12.2 \pm 1.2$ & $20.7 \pm 2.4$ & $558 \pm 84$ \\
\hline$\beta$-glucan & 4 & $1.3 \pm 0.1$ & $4.3 \pm 0.3$ & $4.9 \pm 0.3$ & $7.8 \pm 0.2$ & $12.1 \pm 0.5$ & $21.4 \pm 0.6$ & $588 \pm 23$ \\
\hline Seaweed & 4 & $1.3 \pm 0.1$ & $4.4 \pm 0.1$ & $5.0 \pm 0.1$ & $7.9 \pm 0.3$ & $11.8 \pm 0.8$ & $20.8 \pm 1.3$ & $563 \pm 49$ \\
\hline
\end{tabular}

Value are means \pm standard deviations.

Table 2 Effects of $\beta$-glucan on body weight ( $\mathrm{kg}$ ) and average daily gain (ADG) from 3 weeks to 12 weeks of age (Exp. 2)

\begin{tabular}{|c|c|c|c|c|c|c|c|c|c|c|c|c|c|}
\hline \multirow[b]{2}{*}{ Treatment } & \multicolumn{12}{|c|}{ Weeks of age } & \multirow{2}{*}{$\frac{A D G \text { (g/day) }}{\text { w3-w12 }}$} \\
\hline & w0 & w1 & w3 & w4 & w5 & w6 & w7 & w8 & w9 & w10 & w11 & w12 & \\
\hline $\begin{array}{l}\text { Control } \\
(\mathrm{N}=7)\end{array}$ & $\begin{array}{l}1.3 \\
\pm 0.2\end{array}$ & $\begin{array}{l}1.8 \\
\pm 0.2\end{array}$ & $\begin{array}{l}3.7 \\
\pm 0.7\end{array}$ & $\begin{array}{l}4.7 \\
\pm 0.6\end{array}$ & $\begin{array}{l}6.7 \\
\pm 0.7\end{array}$ & $\begin{array}{l}9.6 \\
\pm 0.8\end{array}$ & $\begin{array}{l}12.2 \\
\pm 1.4\end{array}$ & $\begin{array}{l}15.5 \\
\pm 1.6\end{array}$ & $\begin{array}{l}19.4 \\
\pm 2.4\end{array}$ & $\begin{array}{l}24.9 \\
\pm 2.4\end{array}$ & $\begin{array}{l}29.9 \\
\pm 2.8\end{array}$ & $\begin{array}{l}34.4 \\
\pm 2.6\end{array}$ & $\begin{array}{l}487 \\
\pm 43\end{array}$ \\
\hline $\begin{array}{c}\beta \text {-glucan } \\
(N=8)\end{array}$ & $\begin{array}{l}1.4 \\
\pm 0.2\end{array}$ & $\begin{array}{l}1.8 \\
\pm 0.3\end{array}$ & $\begin{array}{l}3.6 \\
\pm 0.7\end{array}$ & $\begin{array}{l}4.9 \\
\pm 1.2\end{array}$ & $\begin{array}{l}7.2 \\
\pm 1.7\end{array}$ & $\begin{array}{l}10.0 \\
\pm 2.1\end{array}$ & $\begin{array}{l}13.3 \\
\pm 2.4\end{array}$ & $\begin{array}{l}16.7 \\
\pm 2.9\end{array}$ & $\begin{array}{l}22.3^{* *} \\
\pm 3.4\end{array}$ & $\begin{array}{l}27.4 \\
\pm 4.0\end{array}$ & $\begin{array}{l}32.2 \\
\pm 4.0\end{array}$ & $\begin{array}{l}37.6^{*} \\
\pm 4.4\end{array}$ & $\begin{array}{l}540 * * \\
\pm 63\end{array}$ \\
\hline
\end{tabular}

Value are means \pm standard deviations.

** Means between group within the same row differ $(P<0.05)$.

* Means between group within the same row differ $(P<0.10)$.

に $\beta$-グルカンを $0.015 \%, 0.03 \%$ 添加した場合，一日平 均増体量に与える影響はわずかであり，飼料㩒取量が増 加する事を報告している．離乳ストレスによる飼料摂取 の減少は子豚の発育停滞の原因の一つであり, $\beta$-グルカ ンの添加は飼料摂取量の減少を抑えるという点で発育の 改善に有効である可能性が示唆される.しかし今回の実 験では飼料摂取量は測定しておらず，今後飼料摂取量を 測定した上での $\beta$-グルカン添加による発育改善の詳細 な機序の解明が望まれる.

\section{2. 免疫形質}

免疫形質に関して図 1 に試験 1 , 図 2 に試験 2 の結果 を示した。

試験 1 について, $\beta$ 区と海藻区の 5 週齢時の総白血球 数 $\left(1.13 \times 10^{4}, 1.10 \times 10^{4} / \mu \mathrm{L}\right)$ が対照区 $\left(0.88 \times 10^{4} / \mu \mathrm{L}\right)$ よりも大きい值 $(P<0.05)$ を示した. ブタの出生直後 における免疫応答能は他の動物種に比べて低く, 一種の 免疫不全状態にある事が指摘されている（柏崎 1999）. この時期の子豚は白血球が増加してゆく過渡期であり, 総白血球数が多いという事は子豚の免疫を確立するため に必要な条件であると考えられる.Maoら（2005）は中 国産のハーブである Astragalus membranaceus 由来の $\beta$-グルカンを離乳期の子豚の飼料中に添加することに よってTーリンパ球に增殖効果のある事を報告し, 堀 （1996）は海藻中に含まれるレクチンにリンパ球の分裂 促進効果のある事を報告している. 本研究の結果はそれ ら報告を支持すると考えられ, 両添加物の経口摂取が白
血球増殖に関与している可能性が示唆された.

SRBC 接種の一週間後である 7 週齢の補体別経路活性 において $\beta$ 区と海藻区 $(0.81 ， 0.79)$ が対照区 $(0.66)$ よ りも高い値 $(P<0.01)$ となった. 補体は炎症における 主要な反応系であり, 補体別経路活性は自然免疫に属す 液性因子であり，異物に対して膜溶解反応を起こす。そ の反応は C3 と呼ばれる補体タンパクが C 3 転換酵素に よって C3a と C 3b に分解され, C 3b が直接標的に結合 することで活性化される (Ivan ら 1998). 本試験の結果 は $\beta$-グルカンと海藻の両添加物の摂取によって血液中 のC3 転換酵素もしくはC3 から始まる補体別経路に関 わるタンパクが速やかに増加し，異物である SRBC に反

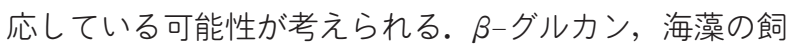
料中への添加によって補体別経路活性が活性化されたと いう報告はこれまでに存在しないため追試験での確認が 望まれる.

顆粒球とリンパ球の比率に関して, SRBC を接種後の 7 週齢において $\beta$ 区（37\%）が対照区（68\%）より低く なった $(P<0.05)$. ブ夕において平常時に顆粒球の最 大の割合を占める好中球はストレスや組織中での炎症に 反応して増加し, リンパ球は減少すること（柏崎 1999）, また輸送ストレスによって好中球とリンパ球の比率（好 中球/リンパ球）が高くなる事がMcGlone ら（1993）に よって報告されており, 顆粒球とリンパ球の比率が高い 事はブ夕にとって好ましくない生理状態であると考えら れる。 $\beta$ 区は対照区と比較して有意に低かった 7 週齢以 

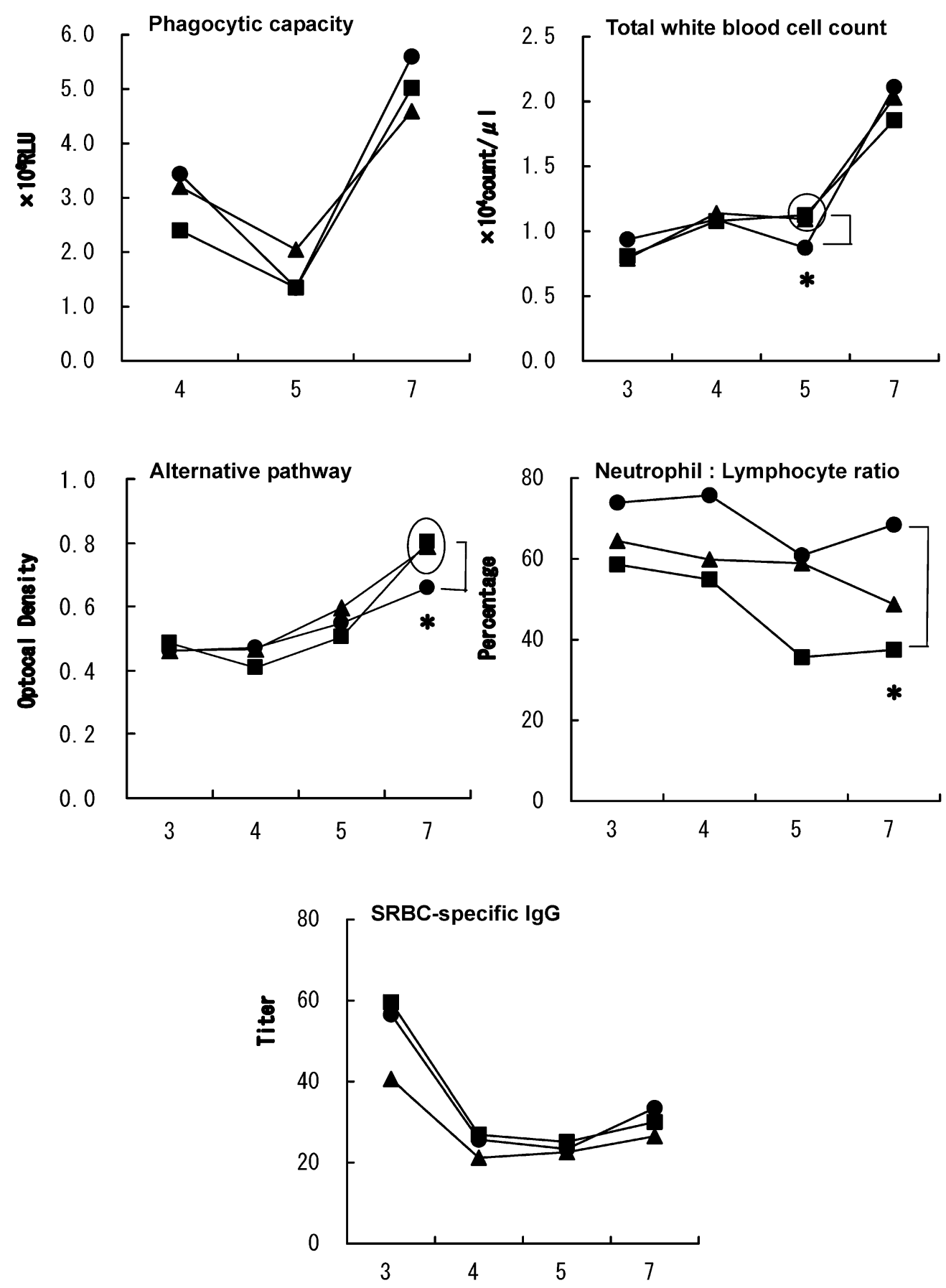

Figure 1 Effect of dietary additives ( $-\mathbf{-}$ : control, $\boldsymbol{-}-\boldsymbol{B}$-glucan, $\boldsymbol{-} \boldsymbol{-}$ : seaweed) for several immune trait. Horizontal scale indicate weeks of age. To show simply, these figure show no SD. Asterisks indicate significant difference between groups that were connected in the line $(P<0.05)$.

外でも平均値で約 15〜25\% ほど小さく推移していた. 試験 2 では 5 週齢時の顆粒球とリンパ球の比率が，対照 区 $(166 \%)$ に比べ $\beta$ 区 $(99 \%)$ で低く $(P<0.05) ， そ$ の他の週齢以外では $\beta$ 区が安定して小さく推移してい た. 以上から $\beta-$ グルカン添加はブタの顆粒球とリンパ 球の比率を低める何らかの効果を持つ可能性が示唆され る.
貪食細胞の活性に関しては両試験を通して添加区の違 いによる有意な差は認められなかった.

免疫形質に関して試験 1 から $\beta$-グルカン, 海藻が免疫 能に影響を与える可能性が示唆されたものの, 試験 $2 て ゙$ は免疫形質に影響する要因は母親の違いが大きく（デー 夕は未掲載), 飼料区による影響は唯一 5 週齢時の好中 球とリンパ球の比率で認められただけであった。今回の 

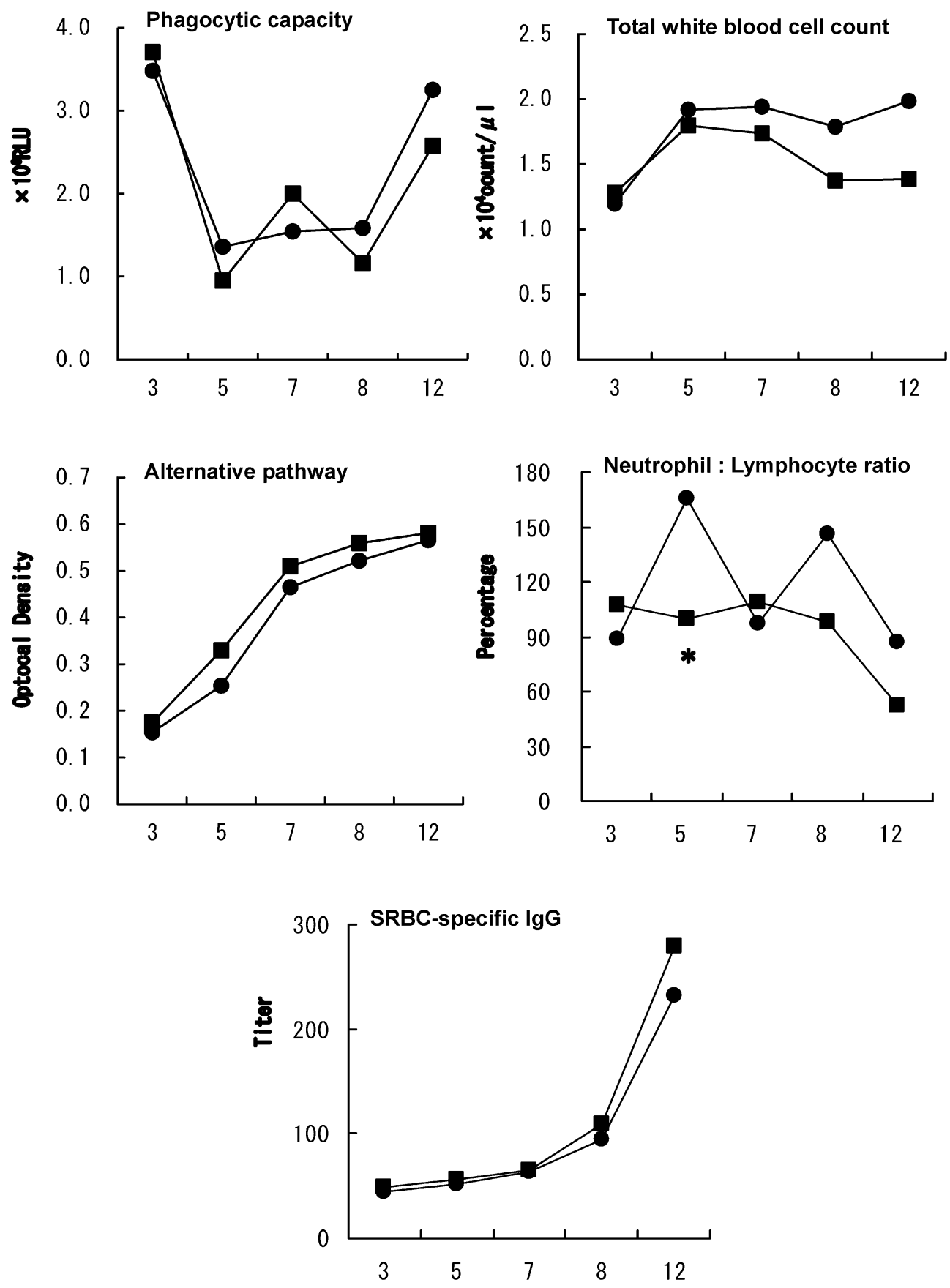

Figure 2 Effect of dietary additives ( $-\mathbf{-}$ : control, $-\mathbf{-}: \beta$-glucan) for several immune trait. Horizontal scale indicate weeks of age. To show simply, these figure show no SD. Asterisks indicate significant difference compared with the control $(P<0.05)$.

免疫形質の結果から，両試験を通じた一定の傾向は認め られなかった。

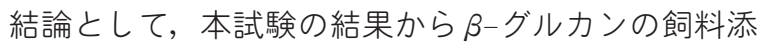
加剂の代替物質として，試験 2 では発育への有効性が, 試験 1 では免疫形質の活性化の可能性が示唆されたもの の，一定した傾向は確認出来なかった.

発育に関して Hahn ら（2006）は，離乳期のブ夕の飼

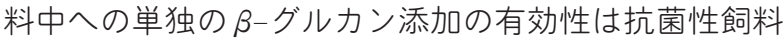
添加剂には及ばない事を報告しており，本試験の結果か

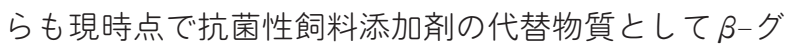
ルカンを利用する事はその効果の面から難しいと考えら

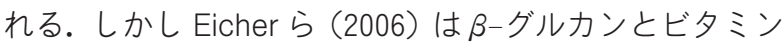
C の両方を飼料中に添加することで発育が最も改善され る事を報告しており， $\beta-$ グルカン, 海藻の生体での作用 
機序には未解明な部分が多く存在していると考えられ る.

それら作用機序を免疫形質として正確に捉えようとす る際には, ブタの低侵襲性の採血方法の確立亡, 可能な 限り短い間隔での採血が望まれる.ブ夕は他の動物種よ りもストレスを感じやすく, 採血の為の保定直後から血 中の性状が変化する（柏崎 1999）。今回の試験では個体 毎の採血にかかった時間を測定していないが，採血時間 には 10 分程度の時間差があったと考えられる．採血時 の測定誤差の減少によるより正確な免疫形質の評価が望 まれる．また免疫形質を評価する際には表型値の比較だ けでは個体ごとの免疫系による防御反応を正確に捉えき れていない可能性（例：ある週齢の形質の活性が低い個 体や集団は, 実際には素早く異物を排除して平常状態ま で戻っているが，それを免疫系による防御反応が低いと 評価してしまう可能性) がある. したがって1週間単位 ではなく一日, 可能であるならば日内での変動を捉えら れるような短い間隔での採血での免疫系の評価が有効で あると考えられる. 免疫形質は, その活性や数値が高い 事が生体において決して有効ではないとする報告（Blecha ら 1994 ; Williams ら 1994）もあり, 免疫形質を評価 する際には目的とする生産性や抵抗性などの形質との相 関関係を考慮する事も重要であると考えられる.

今後も家畜の疾病に対する防御機構, またその防御機 構を活性化すると考えられる物質とその作用機序を探索 する考えである.

\section{謝辞}

本研究を行うにあたり $\beta$-グルカン粉末を提供して下 さった中島水産, 海藻添加物を提供してくださった神協 産業, 動物の飼育に関して協力していただいた宮城県畜 産試験場養豚家きんチームの方々, 宮城大学食産業学部 付属坪沼農場の方々に深く感謝の意を表します。なお本 研究は独立行政法人農業・食品産業技術総合研究機構, 畜産草地研究所の受託試験として行われた。

\section{文献}

Blecha F, Reddy DN, Chitko-McKown CG, McVey DS, Chengappa MM, Goodband RD, Nelssen JL. 1994. Influence of recombinant bovine interleukin-1b and interleukin-2 in pigs vaccinated and challenged with Streptococcus suis. Veterinary Immunology and Immunopathology 44, 329-346.

Dritz SS, Shi J, Kielian TL, Goodband RD, Nelssen JL, Tokach MD, Chengappa MM, Smith JE, Blecha F. 1995. Influence of dietary $\beta$-glucan on growth performance, nonspecific immunity, and resistance to Streptococcus suis infection in weanling pigs. Journal of Animal Science 73, 3341-3350.

Eicher SD, McKee CA, Carroll JA, Pajor EA. 2006. Supplemental vitamin $\mathrm{C}$ and yeast cell wall $\beta$-glucan as growth enhancers in newborn pigs and as immunomodulators after an endotoxin challenge after weaning. Journal of Animal Science $\mathbf{8 4}$,
2352-2360.

Grinstead GS, Tokach MD, Dritz SS, Goodband RD, Nelssen JL. 2000. Effect of Spirulina platensis on growth performance of weanling pigs. Animal Feed Science and Technology 83, 237-247.

Hahn TW, Lohakare JD, Lee SL, Moon WK, Chae BJ. 2006. Effects of supplementation of $\beta$-glucans on growth performance, nutrient digestibility, and immunity in weanling pigs. Journal of Animal Science 84, 1422-1428.

Hiss S, Sauerwein H. 2003. Influence of dietary $\beta$-glucan on growth performance, lymphocyte proliferation, specific immune response and haptoglobin plasma concentrations in pigs. Journal of Animal Physiology and Animal Nutrition 87, 2-11.

Hoffman OA, Olson EJ, Limper AH. 1993. Fungal beta-glucans modulate macrophage release of tumor necrosis factor-alpha in response to bacterial lipopolysaccharide. Immunology Letters 37, 19-25.

堀 貫治. 1996. 21 世紀の海藻資源. pp. 185-206. 緑書房, 東 京.

柏崎 守. 1999. 豚病学. 第 4 版. pp. 65, 69-79. 近代出版, 東京.

小林秀樹. 2004.デンマークにおける成長促進剂としての抗菌 性飼料添加物中止の影響について。日本豚病研究会報 45, $12-48$.

Li J, Li DF, Xing JJ, Cheng ZB, Lai CH. 2006. Effect of $\beta$-glucan extracted from Saccharomyces cerevisiae on growth performance, and immunological and somatotropic responses of pigs challenged with Escherichia coli lipopolysaccharide. Journal of Animmal Science 84, 2374-2381.

Mao XF, Piao XS, Lai CH, Li DF, Xing JJ, Shi BL. 2005. Effects of $\beta$-glucan obtained from the Chinese herb Astragalus membranaceus and lipopolysaccharide challenge on performance, immunological, adrenal, and somatotropic responses of weanling pigs. Journal of Animal Science 83, 2775-2782.

McGlone JJ, Salak JL, Lumpkin EA, Nicholson RI, Gibson M, Norman RL. 1993. Shipping stress and social status effects on pig performance, plasma cortisol, natural killer cell activity, and leukocyte numbers. Journal of Animal Science $\mathbf{7 1}$, 888-896.

Roitto I, Brostoff J, Male D. 1998. 免疫学イラストレイテッド. pp. 43-60. 南江堂, 東京.

Seljelid R, Rasmussen LT, Larm O, Hoffman J. 1987. The protective effect of beta 1-3D-glucan-derivatized plastic beads against Escherichia coli infection in mice. Scandinavian Journal of Immunology 25, 55-60.

Schoenherr WD, Pollmann DS, Coalson JA. 1994. Titration of MacroGard-S on growth performance of nursery pigs (Abstr.). Journal of Animal Science 72 (Suppl. 2), 57.

Turner JL, Dritz SS, Higgins JJ, Minton JE. 2002. Effect of Ascophyllum nodosum extract on growth performance and immune function of young pigs challenged with Salmonella typhimurium. Journal of Animal Science 80, 1947-1953.

Williams NH, Stahly TS, Zimmerman DR. 1994. Impact of immune system activation on growth and amino acid needs of pigs from 6 to $114 \mathrm{~kg}$ body weight. Journal of Animal Science $\mathbf{7 2}$ (Suppl. 2), 57 (Abstr).

山田信夫. 2004. 海藻利用の科学. 改訂版. pp. 186-211. 成山 堂書店, 東京.

全国家畜畜産物衛生指導協会. 2000. 生産獣医療システム 養 豚編. pp. 91-112. 農山漁村文化協会，東京. 


\title{
Effects of dietary $\beta$-glucan and seaweed on growth performance and immune traits in weaning pigs
}

\author{
Wataru ONODERA', Takumi KACHI ${ }^{1}$, Yuuko SHIMIZU², Zyunryou YOSHINO, Zin KOBAYASHI ${ }^{3}$, \\ Yoshito SUDA ${ }^{3}$, and Keiichi SUZUKI ${ }^{1}$ \\ ${ }^{1}$ Graduate School of Agricultural Science, Tohoku University, Aoba, Sendai 981-8555, Japan \\ ${ }^{2}$ Miyagi Prefecture Animal Industry Experiment Station, Osaki 989-6445, Japan \\ ${ }^{3}$ School of Food, Agricultural and Environmental Sciences, Miyagi University, \\ Taihaku, Sendai 982-0215, Japan
}

Corresponding : Keiichi SUZUKI (fax : +81 (0) 22-717-8692, e-mail : k1suzuki@bios.tohoku.ac.jp)

Two experiments were conducted to investigate effects of dietary $\beta$-glucan and seaweed on growth rate and immune traits in peripheral blood of weaning pigs. In experiment 1 , after weaning at 3 weeks of age, 12 Landrace pigs from one litter were allocated to three dietary treatments ( 4 pigs/treatment) : control, $0.025 \%$ $\beta$-glucan supplementation, and $0.05 \%$ seaweed supplementation. The 4 -week experiment continued until the pigs reached 7 weeks of age. In experiment 2, after weaning at 3 week, 16 Duroc pigs from three litters were allocated to two dietary treatments (8 pigs/treatment) : control and $0.05 \% \beta$-glucan supplementation. The experiment continued for 9 week. In experiment 2 , the pigs of $\beta$-glucan treatment exhibited better growth rate $(P<0.05)$. Regarding immune traits in experiment 1 , the pigs consuming $\beta$-glucan or seaweed had higher $(P<0.05)$ total white blood cell counts ( 5 weeks of age) and alternative pathway activity ( 7 weeks of age) than the control group pigs. The control pigs had higher $(P<0.05)$ ratio of granular leukocytes to lymph cells (7 weeks of age in experiment 1 or 5 weeks of age in experiment 2 ). The results suggest that $\beta$-glucan in the diet of weaning pigs may improve growth rate, but its effect on immune traits is still uncertain.

Nihon Chikusan Gakkaiho 79 (3), 377-383, 2008

Key words : $\beta$-glucan, growth rate, immune traits, seaweed, weaning pigs. 